\section{Neuer Sonderforschungsbereich Allergie}

\author{
Die Deutsche Forschungsgemeinschaft hat an der Philipps-Uni- \\ versität in Marburg einen neuen Sonderforschungsbereich bewilligt. \\ Unter dem Titel „Transregio 22" soll in den nächsten Jahren intensiv \\ die Pathogenese allergischer Erkrankungen erforscht werden.
}

s precher des neuen Sonderforschungsbereiches ist Prof. Dr. Harald Renz, Direktor der Abteilung für Klinische Chemie und Molekulare Diagnostik - Zentrallaboratorium - am Klinikum der Philipps-Universität. Weiter an der Initiative beteiligt sind in Marburg die Klinik für Pneumologie, Prof. Dr. Claus Vogelmeier, die Kinderklinik, Prof. Dr. Rolf Maier, und die Medizinische Mikrobiologie und Infektionsimmunologie, Prof. Dr. Michael Lohoff. Ferner ist geplant, die Klinik für Dermatologie und Allergologie unter der Leitung von Prof. Dr. Michael Hertl so bald wie möglich zu assoziieren.
Den Marburger Forschern ist es darüber hinaus gelungen, international anerkannte Forscher außerhalb Marburgs für eine Mitarbeit im Transregio $22 \mathrm{zu}$ gewinnen. Hierzu zählen das LeibnizForschungszentrum in Borstel mit den Arbeitsgruppen um Prof. Dr. Silvia Bulfone-Paus und Prof. Dr. Ernst Rietschel, die renommierte Epidemiologin Prof. Dr. Erika von Mutius vom Dr. von Haunerschen Kinderspital in München und der Mikrobiologe und Immunologe Prof. Dr. Hermann Wagner von der Technischen Universität München.

Das Forscherkonsortium wird sich besonders der Frage zuwenden, warum die Allergieprävalenz in den letzten Deka- den so stark zugenommen hat. Neben einer erblichen Veranlagung sind es offensichtlich unterschiedlichste Umwelteinflüsse, die das Abwehrsystem schon früh im Leben so prägen, dass fehlgeleitete Immunantworten gar nicht erst auftreten. Bei dieser Prägung scheinen Mikroben, wie sie im natürlichen Milieu in der Umwelt vorkommen, eine zentrale Rolle zu spielen. Auch die bakterielle Besiedlung des Darms ist hierbei sicherlich noch eher unterschätzt. Wie dieses Wechselspiel zwischen genetischen Anlagen und Umwelteinflüssen funktioniert, und welche Auswirkungen dies auf die Reifung und Prägung des Abwehrsystems hat, soll vorrangig untersucht werden.

Die Deutsche Forschungsgemeinschaft fördert die Initiative mit jährlich über 2 Millionen Euro. Die Finanzierung ist zunächst für 4 Jahre vorgesehen, eine maximale Förderung für insgesamt 12 Jahre ist möglich. Allein in Marburg werden aus diesen Mitteln 16 Stellen für Wissenschaftler und technisches Personal zusätzlich finanziert.

\section{Klosterfrau Award for Childhood Asthma 2005}

Childhood asthma is one of the great scientific and therapeutic challenges in pediatric pneumology. Its incidence is increasing especially in the industrialized countries. Children suffering of this disease and their parents alike have to go through a painful path of psychic stress and disappointments. Scientists around the world are joining efforts to understand the etiology of this disease, to improve its therapy, and to develop new and more effective therapeutic concepts.

The "Klosterfrau Research-Award for Childhood Asthma" has been installed as an annual prize. It will be awarded to researchers in basic science, pneumology and pediatrics whose work is orientated to the better understanding of childhood asthma.

The prize is endowed with $\mathbf{3 0 . 0 0 0} €$ and will be given to one person or team; $10.000 €$ of this sum are at the individual disposal of the prize winner (winning team), whereas $20.000 €$ have to be spent for further research of the winner or his team.

\section{Guidelines:}

1. The applicant must be under the age of 40 years.

2. Each application must be by a single applicant.

3. The work must be from the past 2 years.

4. The work may be clinical or basic research in asthma, by a researcher whose major clinical training and work have been in pediatrics.

5. Majority of the research work should have been performed by the applicant.

6. Application should contain a short statement of the head of the research group that he/she (the group) supports the application.
7. The applicant must submit a short curriculum vitae and a list of his/her publications.

8. The applicant must submit a summary of his/her work, with an indication of its clinical relevance to childhood asthma and which questions arising from the work need to be answered in the future.

9. Reviews of the literature will not be accepted.

10.Papers or PhD thesis should be presented as a supplement to the application.

11. Universal application form should be used. It must contain:

- Title and full address

- Manuscript(s)

- A summary of the work

- Curriculum vitae and list of publications

- Explanations (by the applicant and the head of the research group that the applicant has performed majority of the research work).

Selection of the award recipient(s) will be made by an international scientific board, made up of six internationally recognized senior scientists. Please send your application ( 8 copies) by November 1st, 2005, at the latest to the Chairman of the International Scientific Board.

\section{Prof. Dr. D. Reinhardt}

Dr. von Haunersches Kinderspital, University of Munich (LMU)

- Klosterfrau-Preis -

Lindwurmstraße 4, 80337 München

E-Mail: dietrich.reinhardt@med.uni-muenchen.de Internet: www.med.uni-muenchen.de/gpp 